\title{
Pengaruh Kapasitas Sumber Daya Pegawai Negeri Sipil, Komitmen Organisasi dan Pemanfaatan Teknologi Informasi Terhadap Penerapan Pengendalian Intern Kas Pada Satuan Kerja Perangkat Daerah (SKPD) di Lingkungan Pemerintah Kota Banda Aceh
}

\author{
Rahmaniar \\ Program Studi Akuntansi Politeknik Kutaraja
}

\begin{abstract}
This study aims to examine the effect of human resource capacity and organizational commitment on the application of cash internal controls at the Regional Work Unit in the Banda Aceh City Government. The population in this study amounted to 36 SKPD and 108 respondents who were self from the Head of Service / Head of Agency / Head of Office as Budget Leaders and Users, SKPD Financial Administration Officers (PPKSKPD) who examined payment request documents and made books on each SKPD cash expenditure, Treasurer of expenditure, Treasurer of receipt if there is cash receipt in the SKPD. Because of this research population, the nature of this research is census. The analytical method used in this study is multiple linear regression. The results of this study indicate simultaneously and partially the variable capacity of civil servant resources, organizational commitment and utilization of information technology affect the implementation of internal cash controls
\end{abstract}

Keywords : PNS resource capacity, organizational commitment, Information Technology Utilization, and Application of Cash Internal Control

Abstrak

Penelitian ini bertujuan untuk menguji pengaruh kapasitas sumber daya manusia dan komitmen organisasi terhadap penerapan pengendalian intern kas pada Satuan Kerja Perangkat Daerah di Lingkungan Pemerintah Kota Banda Aceh. Populasi dalam penelitian ini berjumlah 36 SKPD dan 108 orang responden yangter diri dari Kepala Dinas/Kepala Badan/Kepala Kantor sebagai Pimpinan dan Pengguna Anggaran, Pejabat Penatausahaan Keuangan SKPD (PPK-SKPD) yang memeriksa dokumen permintaan pembayaran dan membuat buku atas setiap pengeluaran kas SKPD, Bendahara pengeluaran, Bendahara penerimaan jika ada penerimaan kas pada SKPD tersebut. Karena penelitian ini populasi maka sifat penelitian ini adalah sensus. Metode analisis yang digunakan pada penelitian ini adalah regresi linier berganda. Hasil penelitian ini menunjukkan secara simultan dan parsial variabel kapasitas sumber daya pegawai negeri sipil, komitmen organisasi dan pemanfaatan teknologi informasi berpengaruh terhadap penerapan pengendalian intern kas.

Kata Kunci : Kapasitas sumber daya PNS, komitmen organisasi, Pemanfatan Teknologi Informasi , dan Penerapan Pengendalian Intern Kas

\section{PENDAHULUAN}

Reformasi birokrasi dan good governance merupakan dua konsep yang sedang diterapkan oleh pemerintah untuk memperbaiki kondisi penyelenggaraan kehidupan berbangsa dan bernegara di indonesia. Melalui reformasi birokrasi, penataan terhadap sistem penyelenggaraan pemerintahan diharapkan akan menjadi lebih efisien, efektif dan ekonomis sebagaimana yang di utarakan oleh kementrian keuangan. Salah satu reformasi birokrasi yang sedang terus dilakukan yaitu reformasi bidang keuangan negara.

Reformasi dalam pengelolaan keuangan Negara ini telah dimulai sejak tahun 2003 dengan ditandai lahirnya paket Undang-Undang dibidang keuangan Negara yaitu Undang-Undang Nomor 17 tahun 2003 tentang keuangan Negara, Undangundang Nomor 1 tahun 2004 tentang perbendaharaan Negara dan Undang-Undang Nomor 15 tahun 2014 tentang Pemeriksaan, Pengelolaan dan Tanggung jawab Keuangan Negara.

Fenomena yang terjadi dalam perkembangan sektor publik di Indonesia dewasa ini adalah menguatnya tuntutan akuntabilitas atas lembagalembaga publik, baik di pusat maupun daerah. Dimensi akuntabilitas publik meliputi akuntabilitas hukum dan kejujuran, akuntabilitas manajerial, akuntabilitas program, akuntabilitas kebijakan, dan akuntabilitas finansial (keuangan), untuk memberikan keyakinan yang memadai mengenai pencapaian tujuan pemerintah daerah yang tercermin dari keandalan laporan keuangan, efisiensi dan efektivitas pelaksanaan program dan kegiatan serta dipatuhinya peraturan perundangundangan (Permendagri Nomor 13 Tahun 2006). 
Anggaran kas merupakan bagian dari anggaran induk sehingga dalam efektivitas penyusunan dan pelaksanaan tergantung pada penerimaan dan pengeluaran kas yang telah disusun sebelumnya. sumber daya manusia dalam suatu organisasi merupakan penentu yang sangat penting bagi keefektifan berjalannya kegiatan didalam organisasi. Keberhasilan dan kinerja seseorang dalam suatu bidang pekerjaan banyak ditentukan oleh tingkat kompetensi, profesionalisme, dan juga komitmennya terhadap bidang pekerjaan yang ditekuninya (Amilin dan Dewi, 2008).

Kapasitas sumber daya manusia adalah kemampuan baik dalam tingkat individu, organisasi/kelembagaan maupun sistem untuk melaksanakan fungsi-fungsi atau kewenangannya untuk mencapai tujuannya secara efektif dan efisien (Laporan akhir studi GTZ \& USAID/CLEAN Urban, 2001). Kapasitas harus dilihat sebagai kemampuan untuk mencapai kinerja, untuk menghasilkan keluaran-keluaran (outputs) dan hasil-hasil (outcomes). Untuk itu setiap Satuan Kerja Perangkat Daerah (SKPD) perlu memperhatikan dan mengatur pegawainya sebagai usaha meningkatkan kinerja yang baik (Triyana, 2009:2).

Komitmen organisasi dari para anggota akan sangat berpengaruh terhadap pengendalian intern kas, karena dengan komitmen yang tinggi akan berdampak terhadap penerapan pengendalian intern kas yang baik pula. Komitmen organisasi yang kuat didalam diri individu akan menyebabkan individu berusaha keras mencapai tujuan organisasi sesuai dengan tujuan dan kepentingan organisasi serta akan memiliki pandangan positif dan lebih berusaha berbuat yang terbaik demi kepentingan organisasi (Porter et al. 1974). berikutnya yang mempengaruhi kinerja instansi pemerintah daerah adalah pemanfaatan teknologi informasi. Teknologi informasi berkaitan dengan pelayanan, hal tersebut dikarenakan salah satu dimensi dari kualitas pelayanan adalah kecepatan pelayanan dimana dimensi tersebut dapat dikaitkan dengan teknologi informasi. Dengan adanya teknologi informasi maka pelayanan yang diberikan, khususnya pada organisasi jasa, akan semakin cepat dan akurat. Implementasi teknologi informasi digunakan untuk membantu dalam pencapaian strategi organisasi.

Pemerintah daerah khususnya aparatur keuangan pemerintah daerah mempunyai tugas melaksanakan tugas umum pemerintahan di bidang pendapatan, pengelolaan keuangan dan aset kota sesuai dengan peraturan perundang-undangan yang berlaku. Pemerintah Kota Banda Aceh dalam mengelola keuangan daerah mengacu pada Permendagri Nomor 13 tahun 2006 yang telah dirubah dengan Permendagri No.59 tahun 2007. Kinerja aparatur keuangan pemerintah daerah adalah unsur pendukung pemerintah kota dibidang pengelolaan keuangan dan kekayaan kota dan dipimpin oleh kepala dinas yang berada dibawah dan bertanggung jawab kepada walikota melalui sekretaris daerah. Pemerintah daerah khususnya aparatur keuangan pemerintah daerah mempunyai tugas melaksanakan tugas umum pemerintahan dibidang pendapatan, pengelolaan keuangan dan aset kota sesuai dengan peraturan perundangundangan yang berlaku. Mengingat peranannya yang sangat penting didalam pengelolaan anggaran daerah maka perlu adanya pengendalian intern kas yang memadai sebagai salah satu tindakan preventif terhadap adanya penyelewengan dan penyalahgunaan dana pembangunan. (Siaran Pers BPK Perwakilan Provinsi Aceh, 2014). Pemerintah Kota Banda Aceh, meskipun memperoleh opini Wajar Tanpa Pengecualian (WTP) yang ke-6 secara berturut-turut untuk laporan keuangan Pemerintah Kota Banda Aceh tahun anggaran 2013. Namun berdasarkan pemeriksaan yang dilakukan oleh Badan Pemeriksa Keuangan (BPK) masih ditemukan beberapa kelemahan yang berkaitan dengan sistem pengendalian intern (SPI) maupun kepatuhan terhadap perundang-undangan.

\section{KAJIAN LITERATUR}

Peraturan Pemerintah Nomor 60 tahun 2008 tentang Sistem Pengendalian Intern Pemerintah telah mendefinisikan pengendalian intern sebagai proses yang integral pada tindakan dan kegiatan yang dilakukan secara terus menerus oleh pimpinan dan seluruh pegawai untuk memberikan keyakinan memadai atas tercapainya tujuan organisasi melalui kegiatan yang efektif dan efisien, keandalan pelaporan keuangan, pengamanan aset negara, dan ketaatan terhadap peraturan perundang-undangan. Tujuan pengendalian intern adalah untuk memberikan keyakinan memadai dalam pencapaian tiga golongan tujuan : (1) keandalan informasi, (2) kepatuhan terhadap hukum dan peraturan yang berlaku, dan (3) efektivitas dan efisiensi operasi (Mulyadi 2002:180).

Keberhasilan dan kinerja seseorang dalam suatu bidang pekerjaan banyak ditentukan oleh tingkat kompetensi, profesionalisme, dan juga komitmennya terhadap bidang pekerjaan yang ditekuninya (Amilin dan Dewi, 2008).Komitmen mencakup juga keterlibatan kerja. Keterlibatan kerja sebagai derajat kemauan untuk menyatukan dirinya dengan pekerjaan, menginvestasikan waktu, kemampuan dan energinya untuk pekerjaan dan menganggap pekerjaannya sebagai bagian utama dari kehidupannya (Mardiana, 2004:177). Semakin kuat komitmen, semakin kuat kecenderungan seseorang untuk diarahkan pada tindakan sesuai dengan standar, dalam Rachmawati (2009). Komitmen organisasi yang kuat akan mendorong individu berusaha keras mencapai tujuan organisasi (Angle dan Perry, 1981; Porter et al., 1974). Komitmen menunjukkan keyakinan dan dukungan 
yang kuat terhadap nilai dan sasaran (goal) yang ingin dicapai oleh organisasi (Supriyono, 2004:601)

Teknologi informasi adalah istilah umum yang menjelaskan teknologi apapun yang membantu manusia dalam membuat, mengubah, menyimpan, mengubah dan mengkomunikasikan informasi (Wiliam dan Sawyer dalam Haryanto, 2012). Dalam pengelolaan APBN yang telah di laksanakan pada tahun-tahun sebelumnya, setiap satuan kerja dibekali dengan pemanfaatan aplikasiaplikasi komputer yang dapat mempermudah pengelolan dan pelaporan penggunaan dana APBN. Dalam hal ini pemerintah sebagai pengguna (user) dari aplikasi-aplikasi tersebut haruslah selalu paham dan up to date atas perubahan-perubahan yang dilakukan oleh Kementrian Keuangan sebagai provider aplikasi. Mulai dari aplikasi rancangan anggaran, pencatatan , sampai dengan pelaporan haruslah selalu di pantau perkembangannya, sehingga dapat menghasilkan laporan keuangan yang tersaji secara benar trasparan dan akuntabel

Secara skematis kerangka pemikiran hubungan antara variabel independen dengan variabel dependen dapat dilihat pada Gambar berikut:

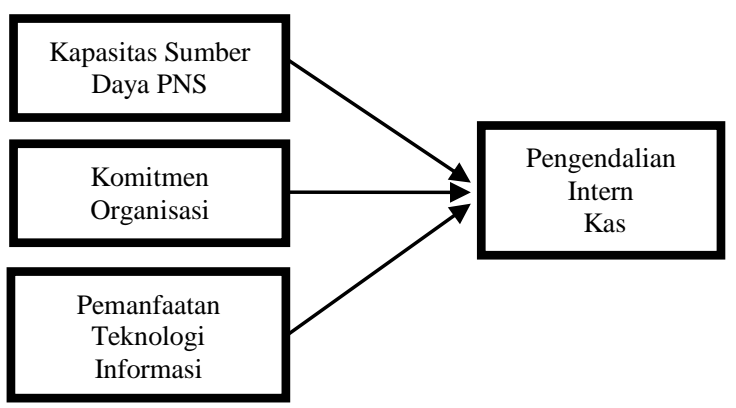

Berdasarkan skema kerangka pemikiran tersebut, maka rumusan hipotesis dalam penelitian ini yaitu kapasitas sumber daya PNS, komitmen organisasi dan pemanfatan teknologi informasi secara bersama-sama maupun secara parsial berpengaruh terhadap penerapan pengendalian intern kaspada satuan Kerja Perangkat Daerah (SKPD) di lingkungan pemerintah kota Banda Aceh.

\section{METODE PENELITIAN}

\section{Populasi Penelitian}

Populasi dalam penelitian ini berjumlah 36 SKPD dan 108 orang responden yangterdiri dari Kepala Dinas/Kepala Badan/Kepala Kantor sebagai Pimpinan dan Pengguna Anggaran, Pejabat Penatausahaan Keuangan SKPD (PPK-SKPD) yang memeriksa dokumen permintaan pembayaran dan membuat buku atas setiap pengeluaran kas SKPD, Bendahara pengeluaran, Bendahara penerimaan jika ada penerimaan kas pada SKPD tersebut.Alasan pemilihan responden tersebut adalah karena dianggap memiliki tanggung jawab atas kapasitas sumber daya PNS, komitmen organisasi dan pemanfaatan teknologi informasi terhadap penerapan Pengendalian Intern Kas. Penelitian ini dilakukan pada 36 Satuan Kerja Perangkat Daerah (SKPD) di Lingkungan Pemerintah Kota Banda Aceh.karena Satuan Kerja Perangkat Daerah tersebut telah menerapkan sistem pengendalian intern. Karena penelitian ini populasi maka sifat penelitian ini adalah sensus.

\section{Teknik Pengumpulan Data}

Teknik pengumpulan data yang digunakan dalam penelitian ini adalahmengedarkan angket pertanyaan dalam bentuk kuesioner. Agar lebih efektif, kuesioner disebarkan dengan cara diantar langsung oleh peneliti kepada responden yaitu pejabat yang berwenang yang terdapat pada masing-masing Satuan Kerja Perangkat Daerah (SKPD) di Lingkungan Pemerintah Kota Banda Aceh.

\section{Rancangan Pengujian Hipotesis}

Kemudian setelah kuesioner terkumpul untuk melakukan analisis data perlu dilakukan uji validitas dan uji reliabilitas.Kedua pengujian ini dilakukan untuk mengetahui apakah alat ukur yang digunakan sesuai dengan yang diukur dan juga melihat konsistensi data yang dikumpulkan. Pengujian validitas dilakukan untuk mengetahui apakah alat ukur yang digunakan dapat mengukur atau mengungkapkan hal-hal yang seharusnya diukur atau diungkapkan. Untuk menguji validitas dilakukan dengan mengkorelasikan masing-masing variabel, dilakukan dengan menggunakan pearson product moment correlation melalui proses SPSS.

Uji reliabilitas dilakukan untuk menguji konsistensi jawaban responden atas seluruh butir pertanyaan atau pernyataan yang digunakan. Uji ini dilakukan apabila pernyataan-pernyataan sudah valid.

Pengujian reliabilitas juga dilakukan secara statistik, yaitu dengan menghitung besarnya nilai Cronbach's Alpha dengan bantuan program SPSS.

Teknik analisis data pada pengujian hipotesis menggunakan analisis regresi linier berganda yang merupakan teknik statistik yang digunakan untuk menguji pengaruh antara dua atau lebih variabel dan untuk melihat pengaruh secara parsial dan simultan. Persamaan model empiris yang digunakan untuk meneliti pengaruh variabel independen terhadap variabel dependen yaitu:

$$
\mathrm{Y}=\alpha+\beta 1 \mathrm{X} 1+\beta 2 \mathrm{X} 2+\beta 3 \mathrm{X} 3+\mathrm{e}
$$

Keterangan:

$$
\begin{array}{ll}
\mathrm{Y} & =\text { Pengendalian intern kas } \\
\mathrm{X} 1 & =\text { Kapasitas sumber daya PNS } \\
\mathrm{X} 2 & =\text { Komitmen organisasi } \\
\mathrm{X} 3 & =\text { Pemanfaatan teknologi informasi }
\end{array}
$$$$
\beta 1, \beta 2, \beta 3=\text { Koefisien regresi } \mathrm{X} 1, \mathrm{X} 2, \mathrm{X} 3
$$ 


\begin{tabular}{rllr}
\hline$\alpha$ & $=$ Konstanta & tingkat signifikansi dibawah 0.05 sehingga \\
$\varepsilon$ & $=$ Error & & kuesioner yang digunakan dinyatakan valid.
\end{tabular}

\section{HASIL PENELITIAN DAN PEMBAHASAN}

Populasi dalam penelitian ini berjumlah 36 SKPD dan 108 orang responden yangterdiri dari Kepala Dinas/Kepala Badan/Kepala Kantor sebagai Pimpinan dan Pengguna Anggaran, Pejabat Penatausahaan Keuangan SKPD (PPK-SKPD) yang memeriksa dokumen permintaan pembayaran dan membuat buku atas setiap pengeluaran kas SKPD, Bendahara pengeluaran, Bendahara penerimaan jika ada penerimaan kas pada SKPD tersebut.Alasan pemilihan responden tersebut adalah karena dianggap memiliki tanggung jawab atas Kapasitas Sumber Daya PNS, Komitmen Organisasi dan pemanfaatan teknologi informasi terhadap penerapan Pengendalian Intern Kas.Penelitian ini dilakukan pada 36 Satuan Kerja Perangkat Daerah (SKPD) di Lingkungan Pemerintah Kota Banda Aceh. jumlah kuesioner yang diterima kembali oleh peneliti sebanyak 108 eksemplar, yang bersedia menjawab atau mengisi kuesioner sebanyak 93, sementara sebanyak 15 kuesioner lagi kosong.

\section{Uji Validitas}

Uji pengujian validitas secara rinci ditampilkan dalam Tabel 4.1

\section{Tabel 4.1}

Hasil Uji Validitas Data

\begin{tabular}{|c|c|c|c|c|}
\hline \\
\hline $\begin{array}{c}\text { Item } \\
\text { Pernyataan }\end{array}$ & Variabel & $\begin{array}{c}\begin{array}{c}\text { Koefisien } \\
\text { Korelasi }\end{array} \\
\end{array}$ & $\begin{array}{c}\text { Nilai Kritis } \mathbf{r} \\
(\mathrm{N}-2)\end{array}$ & Keterangan \\
\hline $\mathrm{A} 1$ & \multirow{10}{*}{$\begin{array}{l}\text { Pengendalian } \\
\text { Intern Kas (Y) }\end{array}$} & 0,498 & 0.202 & Valid \\
\hline $\mathrm{A} 2$ & & 0,659 & 0.202 & Valid \\
\hline $\mathrm{A} 3$ & & 0,560 & 0.202 & Valid \\
\hline $\mathrm{A} 4$ & & 0.503 & 0.202 & Valid \\
\hline A5 & & 0,659 & 0.202 & Valid \\
\hline A6 & & 0,542 & 0.202 & Valid \\
\hline A7 & & 0,503 & 0.202 & Valid \\
\hline A8 & & 0,589 & 0.202 & Valid \\
\hline A9 & & 0,455 & 0.202 & Valid \\
\hline A10 & & 0,621 & 0.202 & Valid \\
\hline A11 & & 0,549 & 0.202 & Valid \\
\hline A12 & & 0,604 & 0.202 & Valid \\
\hline B1 & \multirow{5}{*}{$\begin{array}{l}\text { Kapasitas } \\
\text { Sumber } \\
\text { Daya PNS } \\
\left(\mathrm{X}_{1}\right)\end{array}$} & 0,633 & 0.202 & Valid \\
\hline B2 & & 0,581 & 0.202 & Valid \\
\hline B3 & & 0,637 & 0.202 & Valid \\
\hline B4 & & 0,689 & 0.202 & Valid \\
\hline B5 & & 0,570 & 0.202 & Valid \\
\hline $\mathrm{C} 1$ & \multirow{6}{*}{$\begin{array}{c}\text { Komitmen } \\
\text { Organisasi } \\
\left(\mathrm{X}_{2}\right)\end{array}$} & 0,590 & 0.202 & Valid \\
\hline $\mathrm{C} 2$ & & 0,713 & 0.202 & Valid \\
\hline $\mathrm{C} 3$ & & 0,528 & 0.202 & Valid \\
\hline $\mathrm{C} 4$ & & 0,612 & 0.202 & Valid \\
\hline $\mathrm{C} 5$ & & 0,668 & 0.202 & Valid \\
\hline C6 & & 0,554 & 0.202 & Valid \\
\hline D1 & \multirow{4}{*}{$\begin{array}{c}\text { Pemanfaatan } \\
\text { Teknologi } \\
\text { Informasi } \\
\left(\mathrm{X}_{3}\right)\end{array}$} & 0,753 & 0.202 & Valid \\
\hline D2 & & 0,653 & 0.202 & Valid \\
\hline D3 & & 0,593 & 0.202 & Valid \\
\hline D4 & & 0,697 & 0.202 & Valid \\
\hline
\end{tabular}

Sumber : Data diolah (2016)

Berdasarkan hasil pengujian validitas data menunjukkan bahwa koefisien korelasi yang diperoleh oleh masing-masing item dari variabel kapasitas sumber daya PNS, komitmen organisasi, pemanfaatan teknologi informasi dan pengendalian intern kas berada diatas nilai kritis korelasi product momen (koefisien korelasi >0,202) dan memiliki

\section{Uji Reliabilitas}

Uji pengujian reliabilitas secara rinci ditampilkan dalam Tabel 4.2

Tabel 4.2

Hasil Uji Reliabelitas

\begin{tabular}{|l|c|c|c|}
\hline \multicolumn{1}{|c|}{ Variabel } & $\begin{array}{c}\text { Jumlah } \\
\text { Item }\end{array}$ & $\begin{array}{c}\text { Croncach } \\
\text { Alpha }\end{array}$ & Keterangan \\
\hline $\begin{array}{l}\text { Kapasitas } \\
\text { Sumber Daya } \\
\text { PNS (X })_{1}\end{array}$ & 6 & 0,604 & Handal \\
\hline $\begin{array}{l}\text { Komitmen } \\
\text { Organisasi } \\
\left(\mathrm{X}_{2}\right)\end{array}$ & 6 & 0,658 & Handal \\
\hline $\begin{array}{l}\text { Pemanfaatan } \\
\text { Teknologi } \\
\text { Informasi (X }\end{array}$ & 4 & 0,603 & Handal \\
\hline $\begin{array}{l}\text { Penerapan } \\
\text { Pengendalian } \\
\text { Intern Kas (Y) }\end{array}$ & 12 & 0,800 & Handal \\
\hline
\end{tabular}

Sumber: data diolah (2016)

Berdasarkan Tabel 4.2 nilai koefisien Alpha untuk masing-masing variabel berada diatas 0,60 , sehingga dapat disimpulkan bahwa kuesioner yang dijadikan sebagai alat ukur dalam penelitian ini layak untuk digunakan dalam pengujian lanjutan.

\section{Hasil Pengujian Hipotesis}

Pengujian hipotesis dilakukan untuk menguji serta menganalisis rumusan hipotesis berdasarkan regresi.Pengujian hipotesis tersebut dilakukan sesuai dengan hipotesis yang telah dirumuskan sebelumnya.Hasil pengujian hipotesis ditampilkan pada tabel 4.3.

Tabel 4.3

\section{Hasil Uji Regresi}

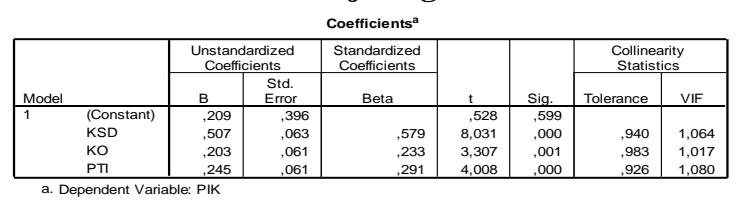

Sumber : data diolah (2016)

Berdasarkan hasil output komputer melalui program SPSS dari nilai coefficients ${ }^{a}$ diatas (Tabel 4.3), maka dapat dijelaskan persamaan regresi berganda sebagai berikut:

$$
Y=0,209+0,507 X_{1}+0,203 X_{2}+0,245 X_{3}
$$

Persamaan regresi dapat diinterpretasikan sebagai berikut:

a. Nilai konstanta berdasarkan persamaan regresi tersebut sebesar 0,209 menyatakan bahwa jika variabel kapasitas sumber daya PNS , komitmen organisasi dan pemanfaatan teknologi informasi bernilai konstan/tetap, maka besarnya nilai penerapan pengendalian intern kas adalah sebesar 0,209 
b. Koefisien regresi kapasitas sumber daya PNS sebesar 0,507, nilai tersebut menyatakan bahwa setiap 100\% peningkatan kapasitas sumber daya PNS maka secara relatif juga akan berpengaruh terhadap penerapan pengendalian intern kas sebesar 50,7\%.

c. Koefisien regresi komitmen organisasi sebesar 0,203 , nilai tersebut menyatakan bahwa setiap $100 \%$ peningkatan komitmen organisasi, maka secara relatif juga akan berpengaruh terhadap penerapan pengendalian intern kas sebesar 20,3\%.

Yang terakhir koefisien regresi pemanfaatan teknologi informasi sebesar 0,245 , nilai tersebut menyatakan bahwa setiap $100 \%$ pemanfaatan teknologi informasi, maka secara relatif juga akan berpengaruh terhadap penerapan pengendalian intern kas sebesar 24,5\%.

\section{Tabel 4.4}

Hasil Uji Determinasi dan Korelasi

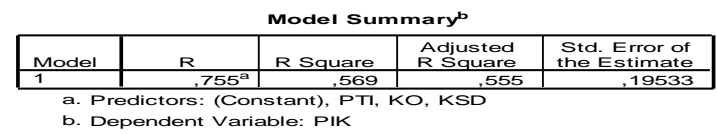

Sumber : data diolah (2016)

1. Kooefisien korelasi (R) sebesar 0,755 menunjukkan bahwa derajat hubungan (korelasi) antara variabel independen dengan variabel dependen sebesar 75,5\%. Artinya kapasitas sumber daya manusia dan komitmen organisasi dan pemanfaatan teknologi informasi mempunyai hubungan terhadap penerapan pengendalian intern kas sebesar $75,5 \%$.

2. Koefisien determinasi $\left(\mathrm{R}^{2}\right)$ sebesar 0,569 artinya penerapan pengendalian intern kas sebesar 56,9\% dipengaruhi oleh kapasitas sumber daya manusia komitmen organisasi dan pemanfaatan teknologi informasi, sedangkan $43,1 \%$ dipengaruhi oleh variabel lain yang tidak dimasukkan dalam penelitian ini.

Hasil penelitian terhadap kapasitas sumber daya PNS $\left(\mathrm{X}_{1}\right)$ diperoleh nilai koefisien $\beta_{1}=0,507$. Berdasarkan hasil perhitungan menunjukkan bahwa secara parsial variabel kapasitas sumber daya PNSberpengaruh terhadap pengendalian intern kas. Maka penelitian ini menerima hipotesis alternatif kedua $\left(\mathrm{Ha}_{2}\right)$ yang menyatakan kapasitas sumber daya PNS berpengaruh terhadappenerapan pengendalian intern kas di lingkungan Pemerintah Kota Banda Aceh. Hipotesis diterima karena nilai $\beta_{1} \neq 0$ yaitu $0,507>0\left(\beta_{1}=0,507 \neq 0\right)$.

Hasil penelitian terhadap variabel komitmen organisasi $\left(\mathrm{X}_{2}\right)$ diperoleh nilai koefisien $\beta_{1}=0,203$. Berdasarkan hasil perhitungan menunjukkan bahwa secara parsial variabel komitmen organisasi berpengaruh terhadap pengendalian intern. Maka penelitian ini menerima hipotesis alternatif kedua $\left(\mathrm{Ha}_{3}\right)$ yang menyatakan komitmen organisasi berpengaruh terhadap penerapan pengendalian intern kasdi lingkunganPemerintah Kota Banda Aceh. Hipotesis diterima karena nilai $\beta_{2} \neq 0$ yaitu $0,203>0\left(\beta_{2}=0,203 \neq 0\right)$.

Hasil penelitian terhadap variabel Pemanfaatan teknologi informasi $\left(\mathrm{X}_{3}\right)$ diperoleh nilai koefisien $\beta_{3}=0,245$. Berdasarkan hasil perhitungan menunjukkan bahwa secara parsial variabel pemanfaatan teknologi informasi berpengaruh terhadap pengendalian intern kas. Maka penelitian ini menerima hipotesis alternatif kedua $\left(\mathrm{Ha}_{4}\right)$ yang menyatakan bahwa pemanfaatan teknologi informasi berpengaruh terhadap penerapan pengendalian intern kas di lingkungan Pemerintah Kota Banda Aceh. Hipotesis diterima karena nilai $\beta_{3} \neq 0$ yaitu $0,245>0\left(\beta_{3}=0,245 \neq 0\right)$.

\section{PENUTUP}

Berdasarkan pembahasan hasil penelitian, maka ditarik kesimpulan sebagai berikut:

1. Secara simultan kapasitas sumber daya PNS, Komitmen organisasi, dan pemanfaatan teknologi informasi berpengaruh positif terhadap penerapan pengendalian intern kas pada satuan kerja Perangkat Daerah (SKPD) di lingkungan pemerintah kota Banda Aceh.

2. Secara parsial kapasitas sumber daya PNS, komitmen organisasi dan pemanfaatan teknologi informasi berpengaruh positif terhadap penerapan pengendalian intern kas pada satuan kerja Perangkat Daerah (SKPD) di lingkungan pemerintah kota Banda Aceh. Saran yang dapat diberikan untuk penelitian berikutnya:

1. Menambah jumlah sampel yang diteliti dan memperluas lokasi penelitian sehingga diharapkan tingkat generalisasi dari analisis akan lebih akurat.

2. Menambah variabel-variabel lain yang memiliki kemungkinan berpengaruh terhadap penerapan pengendalian intern kas dan peneliti selanjutnya menggunakan data sekunder sebagai data penelitian.

\section{DAFTAR PUSTAKA}

Amilin \& Dewi (2008), "Pengaruh Komitmen Organisasi terhadap Kepuasan Kerja Akuntan Publik". Jurnal Akuntansi dan Auditing Indonesia. Volume 12 No. 1: 13-24

Angle, H.L. and J.L. Perry, (1981).An Empirical Assessment of Organizational Commitment and

Organizational 
Effectiveness.Administrative

Science Quarterly26: 1-14.

Haryanto.Agus (2012). Penggunaan Basis Akrual dalam Akuntansi Pemerintahan Indonesia. STIE Dharma Putra, Semarang.

Mardiana, Tri (2004), “ Pengaruh Karakteristik individu Karakteristik Pekerjaan Dan Pengalaman Kerja Terhadap Komitmen Organisasi (Studi Empiris Pada Rumah Sakit Panti Rapih Yogyakarta)", Telaah Bisnis, Vol. 5 No. 2: 175-191.

Mulyadi (2002), Auditing,Jilid I , Jakarta : Salemba Empat

Peraturan Pemerintah Nomor 1 Tahun 2004 tentang Perbendaharaan Negara.

Peraturan Menteri Dalam Negeri No.13 Tahun 2006 Tentang Pedoman Pengelolaan Keuangan Daerah

Peraturan Pemerintah Nomor 17 Tahun 2003 tentang Keuangan Negara

Peraturan Pemerintah Nomor 15 Tahun 2003 tentang Pemeriksaan Pengelolaan dan Tanggung Jawab Keuangan Negara.

Peraturan Pemerintah Nomor 60 Tahun 2008 tentang Sistem Pengendalian Intern Pemerintah (SPIP).
Porter, L. et al. (1974). Organizational commitment, job satisfaction and turnover among psychiatric technicians, Journal of Applied Psychology 59 (5): 603-609.

Rachmawati, Sinta. 2009. Pengaruh Komitmen Organisasi, Motivasi Kerja dan Gaya Kepemimpinan terhadap Kinerja Karyawan Bidang Keuangan pada PEMDA Kabupaten Sukoharjo; Surakarta, Fakultas Ekonomi Universitas Muhammadiyah

Supriono, R.A. 2004. Pengaruh Komitmen Organisasi dan Keinginan Sosial Terhadap Hubungan Antara Partisipasi Penganggaran Dengan Kinerja Manajer.Kumpulan Materi Simposium Nasional Akuntansi VII.Denpasar.

Tim GTZ-USAID/CLEAN Urban.Januari 2001.Pengembangan Kapasitas bagi Pemerintahan Daerah-Suatu Kerangka Kerja bagi Pemerintah dan Dukungan Donor. Laporan Akhir: Studi Pengkajian Kebutuhan Pengembangan Kapasitas bagi Pemerintah Daerah dan DPRD. www.gtzsfdm.or.id

Triyana.C (2006).Visionary Leadership. Jakarta: Bumi Aksara 